\title{
Knowledge of and attitudes towards sexual and reproductive health in adults in Shiraz: a need for further education
}

\author{
M. Khajehei, ${ }^{1}$ S. Ziyadlou ${ }^{2}$ and A. Ghanizadeh ${ }^{3}$
}

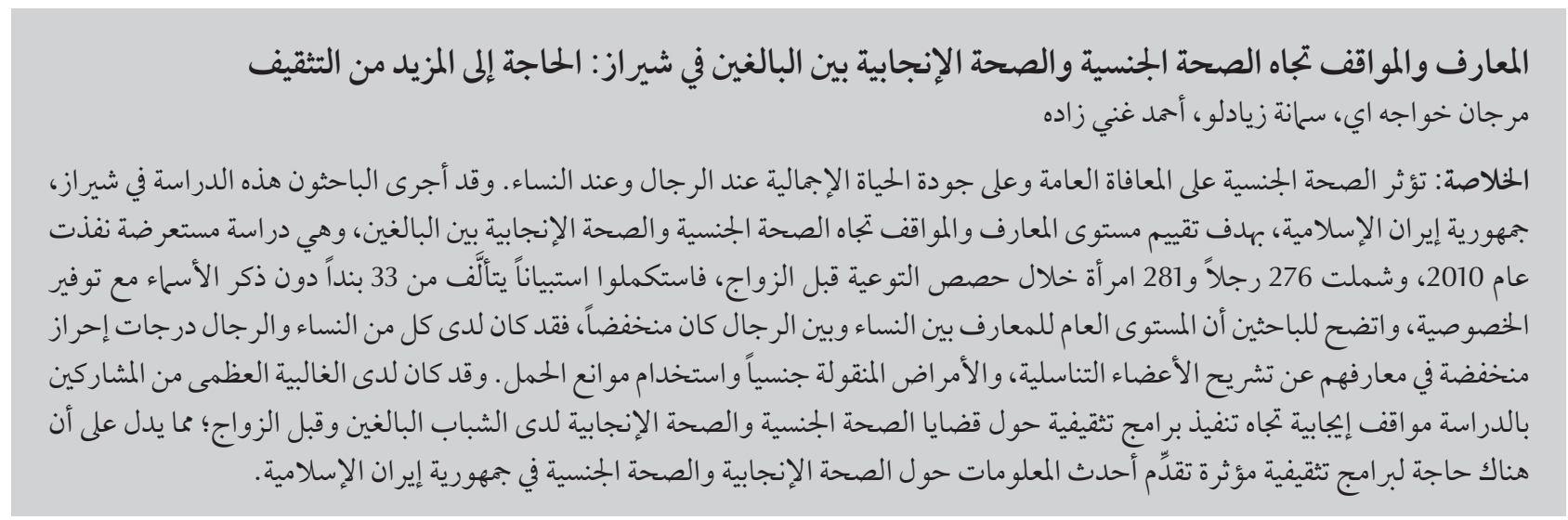

ABSTRACT Sexual health influences general well-being and the overall quality of life of all men and women. This study in Shiraz, Islamic Republic of Iran, aimed to assess the level of knowledge of and attitudes towards sexual and reproductive health among adults. In a cross-sectional study in 2010, 276 men and 281 women were recruited at pre-marital counselling courses and completed a 33-item anonymous questionnaire in private. The overall level of knowledge of men and women was low. Both men and women had low scores on knowledge of genital anatomy, sexually transmitted infections and contraceptive use. The majority of participants had positive attitudes towards implementing educational programmes on sexual and reproductive health issues for young adults and prior to marriage. Efficient educational programmes providing up-to-date information about sexual and reproductive health are needed in the Islamic Republic of Iran.

Connaissances et attitudes en matière de santé sexuelle et génésique chez des adultes de Chiraz : nécessité de renforcer l'action éducative

RÉSUMÉ La santé sexuelle a une influence sur le bien-être général ainsi que sur la qualité de vie globale des hommes et des femmes. La présente étude menée à Chiraz (République islamique d'Iran) visait à évaluer le niveau de connaissances en matière de santé sexuelle et génésique chez des adultes ainsi que leurs attitudes à cet égard. Dans une étude transversale menée en 2010, 276 hommes et 281 femmes participant à des cours de préparation au mariage ont été recrutés et ont complété en privé un questionnaire anonyme comprenant 30 items. Le niveau de connaissances moyen des hommes et des femmes était faible. Les deux sexes ont obtenu des scores faibles en ce qui concerne leur connaissance de l'anatomie des organes génitaux, des infections sexuellement transmissibles et de I'utilisation de la contraception. La majorité des participants étaient favorables à la mise en œuvre de programmes éducatifs sur les questions de santé sexuelle et génésique destinés aux jeunes adultes, avant le mariage. Des programmes éducatifs efficaces fournissant des informations actualisées sur la santé sexuelle et génésique sont nécessaires en République islamique d'Iran.

${ }^{7}$ School of Public Health, Curtin University, Perth, Western Australia, Australia (Correspondence to M. Khajehei: marjan.khajehei@postgrad. curtin.edu.au).

${ }^{2}$ Fatemeh College of Nursing and Midwifery, Shiraz University of Medical Sciences, Shiraz, Islamic Republic of Iran.

${ }^{3}$ Department of Psychiatry, Research Centre for Psychiatry and Behavioural Sciences, Shiraz University of Medical Sciences, Shiraz, Islamic Republic of Iran.

Received: 24/04/12; accepted: 22/05/12 


\section{Introduction}

Sexual health is a necessary part of public health and can significantly influence general well-being and the overall quality of life of all men and women [1]. The World Health Organization (WHO) defines sexual health as "a state of physical, mental and social well-being in relation to sexuality. It requires a positive and respectful approach to sexuality and sexual relationships, as well as the possibility of having pleasurable and safe sexual experiences, free of coercion, discrimination and violence" [2]. Having basic knowledge of the anatomy of the genital organs, healthy sexual behaviours to prevent sexually transmitted infections (STI) and access to health services concerning contraception are known as the fundamental requirements of good sexual and reproductive health (SRH) [3].

The Islamic Republic of Iran is one of the countries with a high rate of STI and induced abortion. One warning sign was a report by WHO about the increasing trend of HIV infection in the country [4]. WHO has also recently reported that unsafe abortions worldwide have risen from 2003 to 2008, and that almost all cases of unsafe abortion have occurred in developing countries such as the Islamic Republic of Iran [5]. It has been reported that lack of knowledge about $\mathrm{SRH}$ is one of the main explanatory factors for current problems with SRH in the Islamic Republic of Iran [6].

The SRH needs of people in developing countries are an underresearched issue in public health and need to be evaluated in order to enable health policy-makers to plan and initiate educational programmes. This study in Shiraz, Islamic Republic of Iran, was conducted in order to assess the level of knowledge of adults on aspects of SRH and to evaluate their attitudes towards SRH issues.

\section{Methods}

\section{Study design and sample}

In this cross-sectional study, a consecutive sample of 600 men and women who were engaged to be married and who registered to enrol in premarital educational classes concerning SRH issues were recruited between January and March 2010. The premarital classes provide information regarding genital anatomy, STI, contraceptive use and sexual relationships of couples. The study was approved by the medical research ethics committee of Shiraz University of Medical Sciences.

\section{Data collection}

A 2-part questionnaire was designed for the study. The first part contained questions about demographic data (sex, age, level of education and job). The second part included customized questions that were generated according to the subjects taught in the educational classes. The questionnaire consisted of 33 closed questions that were to be completed concerning knowledge of participants about genital anatomy of both males (3 questions) and females (3 questions), STI (11 questions) and contraceptive use (9 questions), and attitudes towards SRH (7 questions). Three choices were given for each question: "true" (score 1), "false" (score -1) or "don't know" (score 0). A higher level of knowledge was indicated by a higher positive score. There was no risk of falsepositive or false-negative responses as the survey contained close-ended questions with simple explanations, all of which were true. The score of each domain was calculated by adding the scores of related questions. For instance, knowledge about STI was calculated by adding the scores of 11 questions. A score of 11 would show the highest level of knowledge and a score of -11 would show the lowest level of knowledge regarding STI. In addition, a higher score on attitudes towards SRH issues would show more positive attitudes in this regard.

A panel of 10 experts who were specialized in SRH issues investigated the content validity of the questionnaire and reviewed the test specification and the selection of items. Next, a pilot test was done with 15 men and 15 women attending an educational class. The participants were requested to identify unclear or vague questions and to give comments on terms that were difficult to understand. Then the results of pilot testing were summarized by the panel of experts who reviewed the questionnaire and provided useful feedback. The reviewers also changed the problematic items according to the results of the pilot test and modified the questionnaire based on the individual comments. To test the reliability, the internal consistency of the questionnaire was assessed by Cronbach $a$-coefficient and was found to be 0.79 .

All men and women who referred to the clinic for premarital educational classes were asked to complete the questionnaire before attending the classes. They were informed that participation was entirely voluntary and anonymous. Those who agreed to participate signed a confidential, anonymous consent form and received the questionnaire. All male and female couples were asked to fill in the questionnaires apart from each other and in separate private rooms. The researcher was available at the clinic in another room to answer participants' questions if they did not understand the meaning or aim of any questions. Participants were requested to place the completed questionnaires into a wrapped box. The average time taken to complete each questionnaire was 20-25 minutes per participant, depending on the extent of their knowledge.

\section{Data analysis}

After collecting the questionnaires, the gathered data were analysed using SPSS for Windows, version 15. Descriptive 
statistics [percentages, mean and standard deviation (SD)] were used to summarize demographic data. We used the independent $t$-test in order to compare the knowledge of men and women. The chi-squared test was also used to evaluate the differences between nominal variables. Differences were considered significant when $P$ values were $<0.05$.

\section{Results}

Of the recruited sample 2 men and 2 women refused due to being illiterate and 22 men and 17 women did not complete the questionnaire. Therefore, of the total of 600 individuals participating in this study, 276 men and 281 women filled the entire questionnaire, yielding a response rate of $92.0 \%$ and $93.6 \%$ for men and women respectively.

The mean age of men was 25.5 (SD 5.1) years, range 17-58 years, and of women was 21.2 (SD 4.4) years, range 13-58 years (Table 1 ). The level of knowledge about genital anatomy, STI and contraceptive use was associated with participants' age. Participants (both men and women) aged 20-29 years were more knowledgeable about all aspects of SRH than those in other age groups (13-19 years, 30-39 years, $40-49$ years and $51-58$ years $)(P<$ $0.05)$. Moreover, individuals who had a lower level of education had less knowledge about the 3 aspects of SRH $(P<$ $0.05)$.

\section{Knowledge about genital anatomy}

More men than women knew about the average size of the penis $(P<0.05)$. Although more men who had knowledge about the foreskin and the function of the testes, the majority of both men and women lacked knowledge on these issues $(P>0.05)$. Women had a higher level of knowledge than men on the anatomy of the clitoris, ovaries and hymen $(P<0.05)($ Table 2$)$.

\begin{tabular}{|c|c|c|c|c|}
\hline \multirow[t]{2}{*}{ Characteristic } & \multicolumn{2}{|c|}{$\begin{array}{l}\text { Women } \\
(n=281)\end{array}$} & \multicolumn{2}{|c|}{$\begin{array}{c}\text { Men } \\
(n=276)\end{array}$} \\
\hline & No. & $\%$ & No. & $\%$ \\
\hline \multicolumn{5}{|l|}{ Age (years) } \\
\hline$\leq 20$ & 135 & 48.0 & 21 & 7.6 \\
\hline $21-30$ & 139 & 49.4 & 233 & 84.2 \\
\hline $31-40$ & 5 & 1.8 & 17 & 6.2 \\
\hline$>40$ & 2 & 0.8 & 5 & 2.0 \\
\hline \multicolumn{5}{|l|}{ Education } \\
\hline Primary & 16 & 5.7 & 13 & 4.7 \\
\hline Intermediate & 40 & 14.2 & 64 & 23.2 \\
\hline Secondary & 49 & 17.4 & 39 & 14.1 \\
\hline Diploma & 93 & 33.1 & 89 & 32.2 \\
\hline Associate degree or more & 83 & 29.6 & 71 & 25.8 \\
\hline \multicolumn{5}{|l|}{$J o b$} \\
\hline Employed & 35 & 12.5 & 216 & 78.3 \\
\hline Unemployed & 246 & 87.5 & 60 & 21.7 \\
\hline
\end{tabular}

The mean score of knowledge on genital anatomy was higher among women than men, with no statistically significance difference between groups $(P>0.05)$ (Table 3$)$

\section{Knowledge about sexually STI}

As shown in Table 4, the majority of women did not know that "anal sex should not be done without using a condom" with a statistically significant difference between groups $(P<$ $0.05)$. There was significant difference between men and women regarding knowledge of the 3 issues including "hand shaking, kissing, hugging, sharing dishes, using public toilets and mosquito bites do not increase the risk of HIV transmission", "bloody discharge from genitals is sign of STI in both men and women" and "sores in genital area are signs of STI in both men and women", with men presenting higher level of knowledge on the items $(P<$ $0.05)$. The majority of women did not know that "painful urination is sign of a STI in both men and women" and men showed a higher level of knowledge in this regard $(P<0.05)$. No statistically significant differences were found between men and women regarding their knowledge on other items in this section $(P>0.05)$.

The mean score of knowledge about STI was higher among men than women, with no statistically significance difference between groups $(P>0.05)$ (Table 3)

\section{Knowledge about contraceptive use}

The majority of men and women either had incorrect knowledge on or did not know about contraceptive use (Table 5). Women outnumbered men regarding their level of knowledge of the following items "pregnancy may happen at the first intercourse" and "oral contraceptive pills and progesterone-only injectables are temporary methods of birth control" $(P<0.05)$. On the other hand, more men knew about the low efficacy and reliability of the withdrawal method as a method of birth control $(P<0.05)$ (Table 5). Both men and women had a low level of knowledge on other items in this section with no statistically significant difference between groups $(P>0.05)$.

The mean score of knowledge about contraceptive use did not differ 


\begin{tabular}{|c|c|c|c|c|c|c|c|}
\hline \multirow[t]{3}{*}{ Item } & \multicolumn{3}{|c|}{ Men $(n=276)$} & \multicolumn{3}{|c|}{ Women $(n=281)$} & \multirow[t]{3}{*}{$P$-value } \\
\hline & True & False & $\begin{array}{l}\text { Don't } \\
\text { know }\end{array}$ & True & False & $\begin{array}{l}\text { Don't } \\
\text { know }\end{array}$ & \\
\hline & $\%$ & $\%$ & $\%$ & $\%$ & $\%$ & $\%$ & \\
\hline $\begin{array}{l}\text { Average size of the penis is between } \\
11-15 \mathrm{~cm}\end{array}$ & 59.1 & 5.8 & 35.1 & 32.7 & 16.7 & 50.5 & 0.031 \\
\hline $\begin{array}{l}\text { Testes are the main male sex organs } \\
\text { in which sperm are generated and } \\
\text { mature }\end{array}$ & 34.4 & 6.5 & 59.1 & 29.9 & 8.5 & 61.6 & 0.545 \\
\hline $\begin{array}{l}\text { Foreskin is a sensitive part of the penis } \\
\text { that protects the glans but is removed } \\
\text { during circumcision }\end{array}$ & 27.5 & 69.6 & 2.9 & 24.6 & 70.5 & 5.0 & 0.521 \\
\hline $\begin{array}{l}\text { Clitoris is the most sensitive part of the } \\
\text { female sex organ that is located at the } \\
\text { top of the labia and below the pubic } \\
\text { bone }\end{array}$ & 32.6 & 41.3 & 26.1 & 80.4 & 13.2 & 6.4 & 0.013 \\
\hline $\begin{array}{l}\text { Ovaries are the primary sex organs of } \\
\text { females that produce hormones and } \\
\text { ova (eggs) }\end{array}$ & 8.7 & 25.0 & 66.3 & 44.1 & 8.2 & 47.7 & 0.031 \\
\hline $\begin{array}{l}\text { Hymen is a thin membrane located at } \\
\text { the entry of the vagina that may break } \\
\text { with no noticeable bleeding }\end{array}$ & 5.1 & 70.7 & 24.3 & 72.6 & 23.5 & 3.9 & 0.019 \\
\hline
\end{tabular}

significantly between groups $(P>0.05)$ (Table 3).

\section{Attitudes towards SRH issues}

Regarding Table 6, the majority of men and women believed that young people needed more information regarding SRH issues. Both groups considered parents, professionals and teachers as the main sources of information. They also believed that "education about prevention of pregnancy or STI does not lead to high-risk sexual behaviours", with no significant difference between groups $(P>0.05)$. While the majority of men believed that young adults should access contraceptives before marriage, women did not believe that having access to contraceptives before marriage would be the right option for young adults $(P$ $<0.05)$. A high proportion of men and women believed that "couples should be open to each other and have indepth discussions about SRH matters" $(P>0.05)$.

Although men had a higher mean score for their attitudes towards SRH issues, indicating more positive attitudes, there was no statistically significant difference between groups in this regard $(P>0.05)($ Table 3$)$.

\section{Discussion}

All individuals have sexual feelings and have the right to enjoy sexual activities, regardless of disability or illness. Accordingly, all people need to have reasonable knowledge about SRH in order to be able to achieve a joyful life. Enhancement of knowledge of both men and women concerning SRH may help to promote their quality of life and general well-being [7]. SRH has been regarded in Islam as a significant aspect of human life, and theoretical and practical aspects of reproductive health have been presented in some religious reference texts,

\begin{tabular}{|c|c|c|c|c|c|c|c|}
\hline \multirow[t]{2}{*}{ Variable } & \multicolumn{2}{|c|}{$\begin{array}{c}\text { Men } \\
(n=276)\end{array}$} & \multicolumn{2}{|c|}{$\begin{array}{l}\text { Women } \\
(n=281)\end{array}$} & \multirow[t]{2}{*}{$t$-value } & \multirow[t]{2}{*}{ df } & \multirow[t]{2}{*}{$P$-value } \\
\hline & Mean score & SD & Mean score & SD & & & \\
\hline Genital anatomy & 3.58 & 2.87 & 4.16 & 3.25 & 2.225 & 6.153 & 0.146 \\
\hline Sexually transmitted infections & 4.07 & 2.01 & 3.83 & 2.86 & 1.646 & 0.000 & 0.401 \\
\hline Contraceptive use & 3.40 & 2.93 & 4.57 & 3.34 & 4.378 & 9.360 & 0.213 \\
\hline $\begin{array}{l}\text { Attitudes towards sexual and } \\
\text { reproductive health issues }\end{array}$ & 5.37 & 4.23 & 4.48 & 6.87 & 1.298 & 1.320 & 0.609 \\
\hline
\end{tabular}

$S D=$ standard deviation; $d f=$ degrees of freedom . 


\begin{tabular}{|c|c|c|c|c|c|c|c|}
\hline \multirow[t]{3}{*}{ Item } & \multicolumn{3}{|c|}{$\operatorname{Men}(n=276)$} & \multicolumn{3}{|c|}{ Women $(n=281)$} & \multirow[t]{3}{*}{$P$-value } \\
\hline & True & False & Don't know & True & False & Don't know & \\
\hline & $\%$ & $\%$ & $\%$ & $\%$ & $\%$ & $\%$ & \\
\hline $\begin{array}{l}\text { Anal sex should not be done without using } \\
\text { a condom }\end{array}$ & 33.3 & 53.6 & 13.0 & 20.3 & 18.5 & 61.2 & 0.023 \\
\hline Every condom should be used only once & 91.3 & 0.0 & 8.7 & 81.1 & 0.0 & 18.9 & 0.169 \\
\hline $\begin{array}{l}\text { Having unprotected vaginal sex during } \\
\text { menstrual bleeding may increase the risk } \\
\text { of pelvic infection in women }\end{array}$ & 9.1 & 15.9 & 75.0 & 7.1 & 16.7 & 76.2 & 0.413 \\
\hline $\begin{array}{l}\text { HIV and HBV can be transmitted through } \\
\text { sexual intercourse, sharing contaminated } \\
\text { syringes or mother-to-child during } \\
\text { pregnancy }\end{array}$ & 90.6 & 3.3 & 2.5 & 94.0 & 2.8 & 2.8 & 0.827 \\
\hline $\begin{array}{l}\text { Receiving blood transfusion and using } \\
\text { dentistry services increases the risk of HIV } \\
\text { transmission }\end{array}$ & 9.1 & 3.3 & 87.7 & 7.1 & 6.4 & 86.5 & 0.983 \\
\hline $\begin{array}{l}\text { Hand shaking, kissing, hugging, sharing } \\
\text { dishes, using public toilets and mosquito } \\
\text { bites do not increase the risk of HIV } \\
\text { transmission }\end{array}$ & 76.8 & 5.1 & 18.1 & 59.8 & 25.6 & 15.0 & 0.011 \\
\hline $\begin{array}{l}\text { Bloody discharge from the genitals is sign } \\
\text { of STI in both men and women }\end{array}$ & 68.8 & 4.7 & 26.4 & 45.2 & 18.9 & 35.9 & 0.001 \\
\hline $\begin{array}{l}\text { Sores in genital area are signs of STI in both } \\
\text { men and women }\end{array}$ & 67.0 & 7.2 & 25.7 & 49.5 & 19.6 & 31.0 & 0.041 \\
\hline $\begin{array}{l}\text { Painful urination is sign of STI in both men } \\
\text { and women }\end{array}$ & 39.9 & 19.6 & 40.6 & 22.1 & 23.1 & 54.8 & 0.043 \\
\hline $\begin{array}{l}\text { A person with STI does not necessarily } \\
\text { look ill }\end{array}$ & 3.6 & 10.9 & 85.5 & 4.3 & 7.8 & 84.3 & 0.995 \\
\hline $\begin{array}{l}\text { Abstinence from sex, using condoms } \\
\text { and avoiding used syringes are the most } \\
\text { effective ways of preventing STI }\end{array}$ & 81.5 & 17.8 & 4.3 & 74.0 & 14.6 & 11.4 & 0.096 \\
\hline
\end{tabular}

$H I V=$ human immunodeficiency virus; $H B V=$ hepatitis virus type $B$.

indicating an interest in sexual education [8]. Considering Islam's emphasis on the promotion of SRH, all men and women who are engaged to be married in the Islamic Republic of Iran have to attend educational classes in which issues on SRH are addressed. The classes have been run in each city of the country for more than 15 years.

Our study revealed that the overall level of SRH knowledge of men and women attending the premarital educational classes was very low. Low level of knowledge of sexual reproductive health among Iranian men and women has been found in earlier studies $[9,10]$. The low level of knowledge of participants may be explained by highlighting the impact of several factors. We showed a strong association between age, education and the level of knowledge of participants. These findings seem to be in accordance with those of earlier studies in which age [11] and sociodemographic factors [12] highly affected participants' level of knowledge about SRH. Other studies have shown similar associations between SRH knowledge and various confounding factors such as demographics, social and economic developmental levels and lifestyle $[13,14]$. In contrast, a study among medical college graduates in Pakistan reported that even medical college graduates had low of SRH knowledge and that there was no association between SRH knowledge and academic education [15]. This report suggests that in addition to age and educational level, other factors may impact the level of knowledge of people about SRH.

One possible reason why participants in our study had a low level of SRH knowledge could be cultural issues and religious factors. Gould et al. reported that the level of knowledge of participants was highly affected by their cultural beliefs and religious issues [14]. The relationship between religion and SRH knowledge has also been reported in another study [16]. Although we did not investigate the effect of religious and cultural factors on the level of SRH knowledge of participants, we suggest that adults participating in our study might have been affected by their culture and hence lacked the necessary information on SRH. In many 


\begin{tabular}{|c|c|c|c|c|c|c|c|}
\hline \multirow[t]{3}{*}{ Item } & \multicolumn{3}{|c|}{ Men $(n=276)$} & \multicolumn{3}{|c|}{ Women $(n=281)$} & \multirow[t]{3}{*}{$P$-value } \\
\hline & True & False & Don't know & True & False & Don't know & \\
\hline & $\%$ & $\%$ & $\%$ & $\%$ & $\%$ & $\%$ & \\
\hline Pregnancy may happen at the first intercourse & 6.9 & 12.7 & 82.2 & 12.1 & 26.3 & 59.8 & $<0.001$ \\
\hline $\begin{array}{l}\text { Pregnancy may happen if a woman has unprotected sex } \\
\text { during menstrual bleeding }\end{array}$ & 0.4 & 53.3 & 9.8 & 0.7 & 70.1 & 29.2 & 0.051 \\
\hline $\begin{array}{l}\text { IUD should not be used in nulliparous women (women } \\
\text { who have not given birth to a baby) }\end{array}$ & 6.2 & 15.6 & 78.3 & 6.4 & 17.1 & 76.5 & 0.348 \\
\hline OCP must be taken each day at the same time & 26.4 & 2.9 & 70.7 & 31.0 & 11.7 & 57.3 & 0.325 \\
\hline $\begin{array}{l}\text { OCP and progesterone-only injectables are temporary } \\
\text { methods of birth control }\end{array}$ & 4.3 & 12.7 & 72.1 & 38.8 & 10.3 & 50.9 & $<0.001$ \\
\hline $\begin{array}{l}\text { Concomitant use of some medications, e.g. antibiotics, } \\
\text { antacids, with OCP may reduce the efficacy of OCP and } \\
\text { increase the risk of unwanted pregnancy }\end{array}$ & 2.9 & 1.8 & 95.3 & 1.4 & 3.2 & 95.4 & 0.087 \\
\hline $\begin{array}{l}\text { Efficacy and reliability of withdrawal method(pulling out) } \\
\text { is less than other methods of birth control }\end{array}$ & 38.0 & 13.8 & 48.2 & 27.8 & 11.0 & 61.2 & 0.001 \\
\hline $\begin{array}{l}\text { Male vasectomy and female sterilization are the most } \\
\text { effective methods of birth control }\end{array}$ & 50.0 & 27.9 & 22.1 & 46.6 & 24.6 & 28.8 & 0.068 \\
\hline $\begin{array}{l}\text { Not all kinds of birth control methods suit all people. The } \\
\text { right method should be selected for the right person }\end{array}$ & 4.7 & 7.6 & 87.7 & 7.1 & 11.0 & 84.3 & 0.076 \\
\hline
\end{tabular}

$I U D=$ intrauterine device; $O C P=$ oral contraceptive pills

conservative societies and within many different cultures and religions, young women and men are not exposed to any sexual issues and references before marriage. This idealistic expectation may prevent young adults from obtaining proper information regarding SRH knowledge and may affect their future quality of life.
The mean score of knowledge about STI was low for both male and female participants in our study. Although these findings may not be generalized, they are supported by the WHO report indicating that the most prevalent cause of STI in the Islamic Republic of Iran is lack of knowledge about SRH [4].
We demonstrated that both men and women had a low level of knowledge about contraceptive use. Despite the fact that across the Islamic Republic of Iran family planning services and reproductive health counselling are available free of charge, and in spite of recommendations by healthcare providers regarding proper use of

\begin{tabular}{|c|c|c|c|c|c|c|c|}
\hline \multirow[t]{3}{*}{ Item } & \multicolumn{3}{|c|}{ Men $(n=276)$} & \multicolumn{3}{|c|}{ Women $(n=281)$} & \multirow[t]{3}{*}{$P$-value } \\
\hline & True & False & Don't know & True & False & Don't know & \\
\hline & $\%$ & $\%$ & $\%$ & $\%$ & $\%$ & $\%$ & \\
\hline $\begin{array}{l}\text { Youth need information regarding SRH matters, even if } \\
\text { they do not have premarital sexual relationships }\end{array}$ & 82.6 & 14.1 & 3.3 & 83.3 & 12.5 & 4.3 & 0.918 \\
\hline $\begin{array}{l}\text { Education about prevention of pregnancy or STI does } \\
\text { not lead to high-risk sexual behaviours }\end{array}$ & 66.3 & 13.0 & 20.7 & 62.6 & 17.4 & 19.9 & 0.613 \\
\hline SRH issues need to be taught to students at schools & 60.1 & 33.0 & 6.9 & 58.4 & 33.8 & 7.8 & 0.667 \\
\hline $\begin{array}{l}\text { Parents and professionals are the best sources of } \\
\text { information regarding SRH }\end{array}$ & 83.7 & 14.5 & 1.8 & 83.3 & 13.9 & 2.8 & 0.996 \\
\hline $\begin{array}{l}\text { All young adults should have access to contraceptives } \\
\text { including condoms before marriage }\end{array}$ & 65.9 & 28.3 & 5.8 & 21.7 & 65.8 & 12.5 & 0.007 \\
\hline $\begin{array}{l}\text { Use of contraceptives before marriage may not lead to } \\
\text { infertility }\end{array}$ & 3.6 & 8.3 & 88.0 & 0.7 & 11.7 & 87.5 & 0.776 \\
\hline $\begin{array}{l}\text { Couples should be open to each other and have in- } \\
\text { depth discussions about SRH matters }\end{array}$ & 69.9 & 7.2 & 22.8 & 69.8 & 5.0 & 25.3 & 0.217 \\
\hline
\end{tabular}

$S T I=$ sexually transmitted infections. 
contraceptives, still $30 \%$ of couples who do not wish to conceive do not use any methods of contraception [17]. In addition, statistics show that in spite of the government's efforts, only $55.4 \%$ of Iranian people of reproductive age use contraceptives [18].

The majority of participants in our study believed that sexual health education needed to be implemented in high-school programmes and be taught by trained teachers, parents or professionals. Support for this finding is found in a report of a survey of HIV knowledge and behaviours among 3 high-risk groups in the Islamic Republic of Iran. The study showed that participants were much more likely to be exposed to STI because they acquired information on sexual health mostly from their personal experiences rather than educational programmes for the public [19]. Similar results were reported elsewhere, indicating that the main sources of information on the issue of sexuality for young people were from unreliable resources such as the Internet, friends, books and magazines [20]. According to the results of a study by Barbosa et al. most parents lack knowledge about SRH due to their lack of interest in looking for information [21]. In addition, in some families, parents claimed that they were willing to talk to their children and educate them on this issue; however, the majority of the talks occurred superficially. In fact, many parents report that sexual education has been a challenge for both parents and children [22]. The pivotal role of parents in providing information for children should not be ignored.

The results of the current study should be interpreted with care and may not be generalized to a larger population as we used convenience sampling. In addition, due to the use of a self-report questionnaire, there is possibility of biased responses by the participants.

\section{Conclusions and recommendations}

According to the results of the present study, both men and women in the Islamic Republic of Iran need to be better informed about SRH. While SRH issues are difficult to talk about and discuss openly, clearer health promotion policies need to be issued by health policy-makers. To achieve this goal, there should be efficient educational programmes and a variety of teaching and learning strategies providing up-to-date information.

\section{Acknowledgements}

Funding: this study was funded by the Deputy of Research of Shiraz University of Medical Sciences (grant no. 87-3976).

Competing interests: None declared.

\section{References}

1. Biri A et al. Turkish women's level of knowledge on and attitude toward sexual health. Maturitas, 2007, 58:236-240.

2. Definition of sexual health. World Health Organization [Internet] (http://www.who.int/reproductivehealth/topics/sexual_health/sh_definitions/en/, accessed 2 December 2013).

3. Swartzendruber A, Zenilman J. A national strategy to improve sexual health. Journal of the American Medical Association, 2010, 304(9):1005-1006.

4. Country cooperation strategy at a glance: Iran (Islamic Republic of). Geneva, World Health Organization, 2006 (http:// www.who.int/countryfocus/resources/ccsbrief_iran_irn_06_ en.pdf, accessed 10 May 2013).

5. Department of Reproductive Health and Research. Unsafe abortion: global and regional estimates of the incidence of unsafe abortion and associated mortality in 2008. Geneva, World Health Organization, 2011.

6. Mohammadi MR et al. Reproductive knowledge, attitudes and behavior among adolescent males in Tehran, Iran. International Family Planning Perspectives, 2006, 32:35-44.

7. Kralik D, Koch T, Telford K. Constructions of sexuality for midlife women living with chronic illness. Journal of Advanced Nursing, 2001, 35:180-187.

8. Musallam B. Sex and society in Islam: birth control before the nineteenth century. Cambridge, Cambridge University Press, 1983.

9. Sadeghipour Roudsari HR et al. Reproductive health knowledge, attitudes and practices of Iranian and Afghan men in Tehran province. Eastern Mediterranean Health Journal, 2006, 12:862-872.
10. Nakhaee FH. Prisoners' knowledge of HIV/AIDS and its prevention in Kerman, Islamic Republic of Iran. Eastern Mediterranean Health Journal, 2002, 8:725-731.

11. Mazloomy S, Baghianimoghadam M. Knowledge and attitude about HIV/AIDS of schoolteachers in Yazd, Islamic Republic of Iran. Eastern Mediterranean Health Journal, 2008, 14(2):292-297.

12. Dongxian $Z$ et al. Sexual and reproductive health knowledge among female college students in Wuhan, China. Asia-Pacific Journal of Public Health, 2010, 22(1):118-126.

13. Wilson H, McAndrew S. Sexual health: foundations for practice London, Baillier Tindall, 2000.

14. Gould H, Ellertson C, Corona G. Knowledge and attitudes about the differences between emergency contraception and medical abortion among middle-class women and men of reproductive age in Mexico City. Contraception, 2002, 66:417-426.

15. Khanam M, Perveen S, Mirza S. Reproductive and sexual health issues: knowledge, opinion and attitude of medical graduates from Karachi. Journal of the Pakistan Medical Association, 2011, 61:648-652.

16. Coleman L, Testa A. Sexual health knowledge, attitudes and behaviours: variations among a religiously diverse sample of young people in London, UK. Ethnicity and Health, 2008, 13(1):55-72.

17. Jalal Abbasi-Shavazi M, McDonald P. Fertility decline in the Islamic Republic of Iran: 1972-2000. Asian Population Studies. 2006, 2(3):217-237. 
18. Sadat-Hashemi SM et al. Factors associated with contraceptive use in Tehran, Iran. European Journal of Contraception and Reproductive Health Care, 2007, 12:148-153.

19. Ramezani Tehrani F, Malek-Afzali H. Knowledge, attitudes and practices concerning HIV/AIDS among Iranian at-risk sub-populations. Eastern Mediterranean Health Journal, 2008, 14:142-156.

20. McManus A, Dhar L. Study of knowledge, perception and attitude of adolescent girls towards STIs/HIV, safer sex and sex education: a cross sectional survey of urban adolescent school girls in South Delhi, India. BMC Women's Health, 2008, $8: 12$.

21. Barbosa SM, Costa PN, Vieira NF. Stages of change in parents' discussions with their children about HIV/Aids prevention. Revista Latino-Americana de Enfermagem, 2008, 16:1019-1024.

22. Dias A, Gomes W. Conversas sobre sexualidade na família e gravidez na adolescência: a percepção dos pais [Talking about sexuality in the family and pregnancy of adolescent girls: The parents' perception]. Estudos de Psicologia (Natal), 1999, 4(1):79-106 